\title{
Greening Chilean copper mining operations through industrial ecology strategies
}

\author{
Lorenzo Reyes-Bozo $^{\mathrm{a}, *}$, Alex Godoy-Faúndez ${ }^{\mathrm{b}}$, Ronaldo Herrera-Urbina ${ }^{\mathrm{c}}$, Pablo Higueras ${ }^{\mathrm{d}}$, \\ José Luis Salazar ${ }^{\mathrm{e}}$, Héctor Valdés-González ${ }^{\mathrm{e}}$, Eduardo Vyhmeister ${ }^{\mathrm{f}}$, \\ Blanca Antizar-Ladislao ${ }^{g}$ \\ a Departamento de Ciencias de la Ingeniería, Facultad de Ingeniería, Universidad Andres Bello, Sazié 2315 Santiago, Chile \\ ${ }^{\mathrm{b}}$ Facultad de Ingeniería, Universidad del Desarrollo, Avenida La Plaza 680, Las Condes, Santiago, Chile \\ ${ }^{c}$ Departamento de Ingeniería Química y Metalurgia, Universidad de Sonora, Hermosillo, Mexico \\ d Departamento de Ingeniería Geológica y Minera, Universidad de Castilla-La Mancha, Plaza M. Meca 1, 13400 Almadén (Ciudad Real), Spain \\ e Facultad de Ingeniería, Universidad Andres Bello, Sazié 2325 Santiago, Chile \\ ${ }_{\mathrm{f}}^{\mathrm{f}}$ Departamento de Ingeniería Química, Universidad de Santiago de Chile, Casilla 10233, Santiago, Chile \\ ${ }^{\mathrm{g}}$ School of Engineering, The University of Edinburgh, Edinburgh EH9 3JL, United Kingdom
}

\section{A R T I C L E I N F O}

Article history:

Received 23 September 2013

Received in revised form

25 March 2014

Accepted 28 March 2014

Available online $\mathrm{xxx}$

\section{Keywords:}

Sustainable mining

Biosolids revalorization

Economy

Environment

Community

\begin{abstract}
A B S T R A C T
Sawdust was used as cheap sorbent for the remediation of a diesel and oil fuel-contaminated mining soil whereas biosolids were evaluated as collectors and frothers in froth flotation of copper sulphide ores. The use of these waste materials in copper sulphide ore mining and mineral processing may have a positive impact on the cleaner production of copper from its natural raw sources and may decrease the deleterious effect that mining operations have on the environment. Mixtures of oil fuel contaminated mining soil and sawdust were treated in an aerobic reactor at 50.0\% humidity for several days. A significant decrease (over 60.0\%) of Volatile Organic Compounds (VOCs) content in these mixtures was obtained after one-month of treatment. Rougher flotation of copper sulphide ores using biosolids - from wastewater treatment plants - and humic acids - a component of biosolids - as collector and frother yielded a copper sulphide concentrate with a copper grade and copper recovery of $0.8 \%$ and $26.0 \%$, and $3.5 \%$ and $29.7 \%$, respectively. Biosolids and humic acids have shown to be potential candidates to partially substitute traditional organic chemicals used in industrial flotation of copper sulphide ores. This possibility opens up an alternative for greening copper sulphide ore flotation by using more environmentfriendly flotation reagents. Based on these results, a conceptual model based on industrial ecology and cleaner production principles is proposed for greening the overall copper sulphide ore processing.
\end{abstract}

(c) 2014 Elsevier Ltd. All rights reserved.

\section{Introduction}

Chile is highly vulnerable to impacts of climate changes due to the great diversity of scenarios where economic activities -intensively based on natural resources exploitation - take place (ECLAC, 2010). These anthropogenic impacts are attributed to continued exploitation of natural resources as raw materials for the agriculture, aquiculture and mining industries, the latter being related to ore extraction, mainly copper ores (Schmidt-Hebbel, 2012).

The environmental impacts caused by continual exploitation of natural resources as well as pollution generated by industrial activities are affecting the quality of life of populations inhabiting

\footnotetext{
* Corresponding author. Tel.: +56 2 26618456; fax: +56 226615894 .

E-mail addresses: lreyes@unab.cl, lcreyes@ing.puc.cl (L. Reyes-Bozo).
}

surrounding areas and creating wealth inequalities (Subramanian and Kawachi, 2004).

A good example of controversial tradeoffs between economic growth and environmental pollution is the Chilean copper mining sector, where the relationship between the mining industry and society has historically been complex (Oyarzún and Oyarzún, 2011).

The aim of this paper is to provide a conceptual model based on concepts from industrial ecology and cleaner production through the use of environment friendly waste products for greening the mining and mineral processing steps during copper production. These concepts could be a complement to technological innovation, which plays a fundamental role in the long-term development of cleaner production improving the sustainability and performance of mineral processing operations by reducing impacts on the environment. 
In Chilean copper mining operations, copper sulphide ores predominate over copper oxide ores (Bulatovic, 2007). According to statistics from the Chilean Copper Commission (Cochilco, 2013a), in the year 2012 domestic copper mining operations had an annual handling capacity to concentrate 450 million tonnes of copper sulphide ore by froth flotation, yielding 3.7 million tonnes of fine copper. It is projected that for the year 2021, the installed capacity to process copper sulphide ores will increase to around 1200 million tonnes whereas fine copper production will reach 6.8 million tonnes.

Over the period 2001-2011, the total energy consumption of the Chilean copper mining operations increased 59.6\%, from 86.2 to 137.6 PJ. During this period, fuel consumption (i.e., diesel, natural gas, coal, etc.) rose from 39.0 to $65.7 \mathrm{PJ}$, whereas electrical energy consumption increased from 47.2 to $71.9 \mathrm{PJ}$. Areas with a more intensive use of energy in 2011 were mining exploitation (40\%), concentrating plants (25\%) and treatment of oxide ores (21\%). It is projected that for the year 2020, Chilean copper mining operations will consume $141.8 \mathrm{PJ}$ in electricity. Concentrating plants will consume 56\% of the total energy employed in mining, whereas desalination plants and drive systems are projected to consume 14\% (Cochilco, 2013c).

In the year 2011 the Chilean copper mining operations consumed $12.6 \mathrm{~m}^{3} / \mathrm{s}$ of fresh water (about $400 \times 10^{6} \mathrm{~m}^{3}$ ). Out of this total water consumption, pyrometallurgical production of copper accounted for $71 \%$, whereas hydrometallurgical production of copper represented $14 \%$. Mine water, drinking water and other services accounted for the remaining $15 \%$. Water consumption per tonne of ore treated in the concentrating plant and hydrometallurgical processing is $0.65 \mathrm{~m}^{3}$ and $0.12 \mathrm{~m}^{3}$, respectively. It is expected that demand for fresh water in 2020 will be $17.1 \mathrm{~m}^{3} / \mathrm{s}$ (about $\left.540 \times 10^{6} \mathrm{~m}^{3}\right)$ (Cochilco, 2013c).

The copper pyrometallurgical process (Fig. 1) includes five basic stages: 1) comminution, aimed at reducing ore particle size; 2) froth flotation, for obtaining copper minerals concentrate; 3) smelting, to separate the metal from its minerals; 4) converting, aimed at obtaining blister copper, and 5) electrorefining, to purify resulting final products (Biswas and Davenport, 2002; Memary et al., 2012). Every stage requires raw materials, chemical reagents as well as water (Gunson et al., 2012) and energy consumption (Northey et al., 2013), which translates into high levels of environmental impacts due to dust and gaseous emissions $\left(\mathrm{CO}_{2}\right.$, $\mathrm{SO}_{2}$ ), wastewater discharges containing persistent chemicals, and solid wastes (slags and tailings) disposal.

In general, all steps shown in Fig. 1 are highly energy-intensive and generate hazardous waste materials (Memary et al., 2012; McLellan and Corder, 2012; Moors et al., 2005); however copper smelting and matte converting are autogenous processes requiring less energy.

Other environmental impacts of the mining industry are the production of hazardous wastes by discharges and drainage resulting from daily operation of heavy machinery, where repetitive spills of fuel oil have occurred during their repair and maintenance as well as casual accidents. In many cases soils and sawdust have been used as cheap and readily available adsorbent materials to help the cleanup which must be contained in Hazardous Wastes Landfills (HWL). Current Chilean legislation contemplates bioremediation technologies, such as composting (Antizar-Ladislao et al., 2004), as a valid alternative practice to environmental decontamination (Minsal, 2004), although this green technology needs to be experimentally tested, as argued by Godoy-Faúndez et al. (2008). The composting process applied on soil to remove organic pollutants can be a useful treatment to transform hazardous wastes into inert wastes to be disposed of in a landfill to avoid environmental and human risks.

Froth flotation uses chemical reagents (collectors, frothers and modifiers) to control the wettability of solid surfaces, the electrochemistry of the solution, the dispersion and aggregation of solid particles, and the generation of foam (Herrera-Urbina, 2003). In this way, it is possible to recover mineral species of interest and to prevent the flotation of unwanted gangue minerals.

Because average copper grades of copper sulphide ores in Chile have decreased from $1.18 \%$ to $0.90 \%$ over the period $2003-2012$ (Cochilco, 2012), greater consumption of water, energy and chemical reagents is required to efficiently process low-grade copper sulphide ores. In particular, the consumption of collectors, frothers and modifiers in froth flotation is increasing because higher amounts of low-copper grade ore are processed. For example, the average concentration of collectors and frothers being used in 2012 was $50 \mathrm{~g} / \mathrm{t}$ ore and $30 \mathrm{~g} / \mathrm{t}$ ore, respectively. These concentrations correspond to 26,243 tonnes of collectors and 15,745 tonnes of frothers per year. Both of these chemicals represent expensive reagents that pose environmental risks due to their properties such as flashpoint, high vaporization rates and residual chemical properties, which produce an unpleasant odor in warmer climates (classified as hazardous materials for potential health effects) (Chockalingam et al., 2003; Ralston, 2002; Tan et al., 2005).

The copper sulphide minerals industry of Chile may be able to find new environment-friendly reagents for froth flotation through new strategies and concepts from industrial ecology, cleaner production, green chemistry, life cycle assessment and sustainable engineering (Basu and van Zyl, 2006; McLellan et al., 2009; Laurence, 2011) as well as new uses for inert materials after bioremediation processes by composting.

\section{Biosolids generation and disposal}

Chile will achieve at least $98 \%$ of household wastewater treatment by 2013, according to statistics and forecasting from Superintendencia de Servicios Sanitarios (Superintendency of Sanitary Services, SISS). Activated sludge has been the main technology deployed at national level, accounting for $51 \%$ of total production (SISS, 2010). The accomplishment of this national goal has translated into large organic waste volumes (called sludge or biosolids) that need to be disposed of according to national legislation based on international standards. Biosolids generators are mainly located

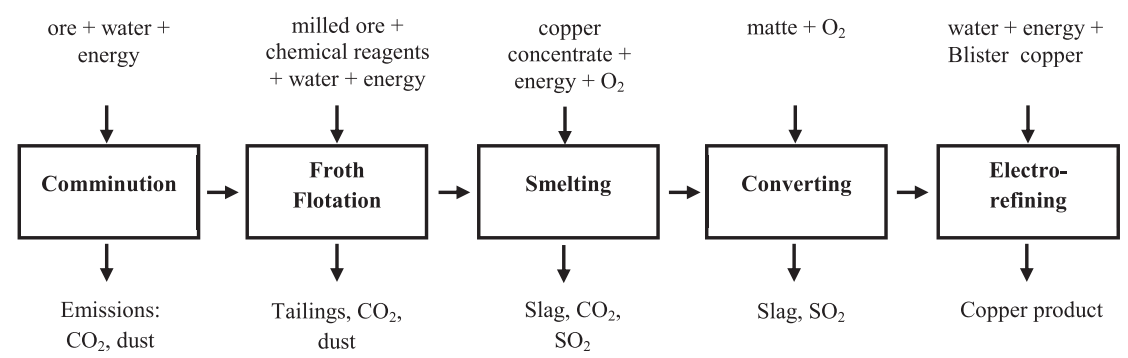

Fig. 1. Flowchart of copper production in a pyrometallurgy operation showing the inputs and outputs at each process step. 
in the central and southern regions of Chile (see Fig. 7), the Metropolitan Region (MR) and regions V and VIII being the most important producers (220,000 tonnes/year). Indeed, in the Santiago Metropolitan area alone (see Table 1), with seven million inhabitants, around 160,000 metric tonnes of biosolids are produced annually (SISS, 2010).

Generated biosolids constitute an environmental challenge because they need adequate management as well as a special final disposal method. Considering that biosolids contain high levels of organic matter (such as humic acids) and nutrient contents (N, P, K), they constitute potential soil improvers and conditioners. Biosolids are known to supply the nutrients required for crop production (Sommers, 1977; Singh and Agrawal, 2008) and to improve soil chemical and physical properties (Wei et al., 1985). This waste has also been used as amendment in agriculture, forestry, recovery of degraded soils and phytostabilization of tailings (Langer, 1998; McFarland, 2000; Verdugo et al., 2010). However, value adding choices for biosolids in Chile are limited by factors such as soil physicochemical and biological characteristics, public acceptance and regulatory frameworks of appropriate controls established at government level (Minsegpres, 2009). In Chile, final disposal of biosolids is limited to landfills and monofills (SISS, 2010).

Internationally, mainly in the United States and Europe, incineration and co-incineration are the preferred methods of final disposal of biosolids (US EPA, 1995). Incineration produces a minimum of ash (Campbell, 2000) and this method is effective when the ground is limited. However, this technique is expensive because it requires preliminary drying of biosolids and combustion should be maintained with additional fuel.

From the industrial ecology viewpoint, biosolids and sewage sludge are fluxes of mass and energy that can be recovered by anaerobic digestion or incineration. Today, the use of these wastes has been applied in cement and clay brick manufacturing. Sludge provides chemical components such as $\mathrm{CaO}, \mathrm{SiO}_{2}, \mathrm{Al}_{2} \mathrm{O}_{3}$, and $\mathrm{Fe}_{2} \mathrm{O}_{3}$ as well as ash by incineration, which replaces raw materials in brick manufacturing (Murray et al., 2008), thus decreasing emissions and resource consumption. However, new uses must be studied to link different industrial activities by fluxes of mass and energy by promoting energy efficiency and reduction of consumption via replacement of chemical reagents.

A feasible and novel solution could resolve these needs by finding applications for humic substances and biosolids. These organic materials may be used as cheap environment-friendly collectors and frothers for froth flotation processes (Park et al., 2008; Guellil et al., 2001; Reyes-Bozo et al., 2011a, 2011b, 2011c).

\section{Experimental}

\subsection{Bioremediation of contaminated mining soils}

\subsubsection{Materials}

The soil sample used in this research work was from a mining area of Minera Escondida, Ltd., which is located in the Atacama

Table 1

Biosolids' production worldwide (adapted from LeBlanc et al., 2008).

\begin{tabular}{lll}
\hline Country & Biosolids' production (dry metric tonnes) & Population \\
\hline Brazil & 372 & $188,078,000$ \\
Canada & 550 & $33,100,000$ \\
Chile ${ }^{\mathrm{a}}$ & 160,000 & $7,000,000$ \\
China & $2,966,000$ & $1,313,974,000$ \\
Germany & $2,000,000$ & $82,422,000$ \\
Italy & $1,000,000$ & $58,134,000$ \\
Japan & $2,000,000$ & $127,464,000$ \\
USA & $6,514,000$ & $298,444,000$ \\
\hline
\end{tabular}

${ }^{a}$ Annual rate for Santiago, Chile. desert in the north of Chile, and has been characterized by standard methods according to USDoA (1999) (Table 2). This soil ( $>10$ mmhos $\mathrm{cm}^{-1}$, extremely saline, sandy loam) has been polluted over the years by frequent accidental fuel oil spills from routine maintenance of mining machinery and trucks. The oil spills were contained using desert soil and sawdust as a cheap adsorbent, and disposed in separate sealed vessels in a Hazardous Waste Landfill (HWL), as required by current Chilean legislation (Minsal, 2004) to avoid exposure to direct-solar radiation as well as physical and chemical removal.

Sealed vessels containers were selected by random method to prepare composite samples of soils and sawdust, respectively. $80 \mathrm{~kg}$ of composite samples of contaminated desert soil (main contaminant present: diesel fuel -hydrocarbons in the $C_{10}-C_{19}$ range) and $40 \mathrm{~kg}$ of composite samples of contaminated sawdust (main contaminant present: fuel oil -hydrocarbons in the $C_{4}-C_{13}$ range), previously kept for two years in HWL, were provided to our laboratory. The quantification of hydrocarbon was performed by Standard EPA Method 8260 B and 8270, respectively (USEPA, 2005). The contaminated samples of desert soil and contaminated sawdust were air-dried, homogenized by passing them separately through a $5 \mathrm{~mm}$ sieve followed by a $2 \mathrm{~mm}$ sieve, and stored in the laboratory at room temperature in the dark.

\subsubsection{Method}

Contaminated mining soil was treated in 30 cylindrical $(50 \mathrm{~cm}$ long, $22 \mathrm{~cm}$ internal diameter; $5 \mathrm{~L}$ total capacity) poly-vinylchloride aerated composting reactors operating continuously during 56 days with sampling every 15 days in triplicate (AntizarLadislao et al., 2006). The moisture content inside all reactors was measured gravimetrically and adjusted to $50 \%$ by adding sterilized distilled water.

Five ratios of contaminated soil vs contaminated sawdust (S:SD, wet weight) were used: $1: 0$ (only soil), $3: 1,1: 1,1: 3$ to $0: 1$ (only sawdust). Abiotic controls using the same $S: S D$ ratios were also performed but they were radiated with Gamma rays from a Cesium 137 source, to $25 \mathrm{kGy}$ doses, three times in an Experimental Nuclear Reactor (Chilean Commission of Nuclear Energy, CCHEN). Atmospheric air previously warmed at $60{ }^{\circ} \mathrm{C}$ was introduced into each

Table 2

Initial physico-chemical characteristics of contaminated mining soil and sawdust compared to other soils.

\begin{tabular}{|c|c|c|c|c|}
\hline & \multicolumn{2}{|c|}{$\begin{array}{l}\text { Soil and sawdust used in } \\
\text { this study }\end{array}$} & \multicolumn{2}{|l|}{ Other soils } \\
\hline & $\begin{array}{l}\text { Contaminated } \\
\text { mining soils }\end{array}$ & $\begin{array}{l}\text { Contaminated } \\
\text { sawdust }\end{array}$ & $\begin{array}{l}\text { Kuwait } \\
\text { (Al-Awadhi } \\
\text { et al., 1996) }\end{array}$ & $\begin{array}{l}\text { Atacama } \\
\text { soils }\end{array}$ \\
\hline pH susp & 7.3 & 7.4 & $7.5-8.0$ & $7.0-8.0$ \\
\hline EC susp (mmhos/cm) & 10.0 & 12.5 & 0.6 & $>10$ \\
\hline TOC & $14 \%$ & NA & $<0.02 \%$ & $<0.1 \%$ \\
\hline $\begin{array}{l}\text { Cultivable heterotrophic } \\
\text { bacteria }\left(\mathrm{CFU} \mathrm{g} \mathrm{g}^{-1}\right)\end{array}$ & $10^{5}$ & $10^{6}$ & $10^{5-6}$ & NA \\
\hline $\begin{array}{l}\text { Soil water holding } \\
\text { capacity }\end{array}$ & NA & NA & $6 \%$ & $4 \%-5 \%$ \\
\hline Texture & Sandy Loam & NA & Sandy Loam & NA \\
\hline Total N (mg/kg) & 1100 & 4100 & NA & NA \\
\hline Total P (mg/kg) & 1110 & 1600 & NA & NA \\
\hline Total K (mg/kg) & 2110 & 9800 & NA & NA \\
\hline Total S (mg/kg) & 3000 & 3350 & NA & NA \\
\hline Ava $\mathrm{N}(\mathrm{mg} / \mathrm{kg})$ & 148.3 & 285.7 & NA & NA \\
\hline Ava P (mg/kg) & 12.3 & 16.8 & NA & NA \\
\hline Ava K (mg/kg) & 214.0 & 340.7 & NA & NA \\
\hline Ava S (mg/kg) & 2210.8 & 2239.1 & NA & NA \\
\hline Total $\mathrm{Cu}(\mathrm{mg} / \mathrm{kg})$ & 741.9 & 248.9 & NA & NA \\
\hline Total Fe (mg/kg) & 6.4 & 22.7 & NA & NA \\
\hline
\end{tabular}

Ava, available; NA, data not available or not applicable. 
reactor and circulated through an internal perforated piping to ensure a sufficient oxygen concentration in the reactors. Type $K$ thermocouples were inserted vertically in the center of vessels to record temperature changes. Recorded temperatures throughout the length of the treatment showed that the composting reactors reached mesophilic temperatures.

Sampling and quantification of diesel and fuel oil content of sample were conducted following USEPA SW-846 8260B methods for VOC (defined as volatile organic compounds having an initial boiling point lower than or equal to $250{ }^{\circ} \mathrm{C}$ measured at a standard atmospheric pressure of $101.3 \mathrm{kPa}$ ) (US EPA, 2005) in accredited laboratories. Samples were taken every 15 days ( $t_{0}$, initial conditions). Chemical analyses of VOCs were performed at CENMA accredited laboratory for environmental analysis in Chile (US EPA, 2005).

\subsection{Evaluation of the use of biosolids and humic acids as froth flotation agents}

\subsubsection{Materials}

Two samples of copper sulphide ore were used in froth flotation tests conducted at laboratory scale. Both ore samples were milled and free of chemical reagents. Their $D_{50}$ particle size is close to $90 \mu \mathrm{m}$.

One sample, provided by a Chilean mining company, was obtained from a pit in the central-northern region of Chile, and contained $7415 \mathrm{mg} / \mathrm{kg}$ of total copper and $38140 \mathrm{mg} / \mathrm{kg}$ of total iron quantified by atomic absorption spectrophotometry with a Perkin Elmer Analyst 300 apparatus. The main mineralogical species of this ore were chalcopyrite $(0.7 \%)$, pyrite $(0.1 \%)$ and molybdenite (0.1\%), while the gangue accounted for $98.4 \%$. Another copper sulphide ore sample with $0.94 \%$ copper grade was obtained from the central-southern Chile and contained chalcopyrite (0.65\%), molybdenite $(0.01 \%)$, pyrite $(0.92 \%)$ and gangue minerals $(98.4 \%)$. The mineralogical analysis was performed by standard methods according to Gaines et al. (1997). The composition of these copper sulphide ores agree with data reported by Bulatovic (2007).

The biosolids used in froth flotation tests were obtained from the wastewater treatment plant El Trebal (Aguas Andinas S.A., Santiago, Chile). In this plant, the biological removal of the organic load is performed using activated sludge technology. Biosolids samples obtained from the monofill $(23 \% \mathrm{w} / \mathrm{w}$ moisture) were previously ground, homogenized and sieved to a fraction of less than $1 \mathrm{~mm}$. Biosolids are composed of organic matter $(55.0 \% \mathrm{w} / \mathrm{w}$, dry basis), $31.7 \%$ of total organic carbon (Walkey and Black method) and $4.4 \%$ of total nitrogen (Kjeldahl method). Biosolids also contain a significant concentration of $\mathrm{P}(21,210 \mathrm{mg} / \mathrm{kg}), \mathrm{Ca}(20,313 \mathrm{mg} / \mathrm{kg})$ and $\mathrm{SO}_{4}{ }^{2-}(1000 \mathrm{mg} / \mathrm{kg})$ with the presence of $\mathrm{Cu}(407 \mathrm{mg} / \mathrm{kg}), \mathrm{Fe}$ $(17,382 \mathrm{mg} / \mathrm{kg})$ and Mo $(21 \mathrm{mg} / \mathrm{kg})$. The metal contents were determined by atomic absorption spectrophotometry with a Perkin Elmer Analyst 300 apparatus.
Biosolids also contain humic substances, mainly fulvic acids (3.0\%) and humic acids (13.8\%) quantified by standard method (Sadzawka et al., 2006). A more detailed chemical and physical characterization can be found in Reyes-Bozo et al. (2011b).

Commercial humic acid was used in froth flotation tests. These substances show the presence of metals at the trace level, mainly Fe (6000 ppm) and Cu (50 ppm). According to Pandey et al. (1999), humic acid has a characteristic composition of $44.67 \%$ organic carbon, $5.87 \%$ hydrogen, $4.88 \%$ total nitrogen, $43.9 \%$ oxygen and $0.58 \%$ ash with a total acidity of $12.3 \mathrm{~mol} / \mathrm{kg}$. The concentrations of functional groups such as $-\mathrm{COOH}$ and phenolic $-\mathrm{OH}$ are 4.1 and $8.2 \mathrm{~mol} / \mathrm{kg}$, respectively.

\subsubsection{Method}

To evaluate the collector and frother capabilities of biosolids and humic acids, rougher froth flotation tests were conducted in a Denver Cell at laboratory scale using the copper sulphide ore from the central-northern region of Chile. For comparison, froth flotation of this ore using the dosages of collectors and frothers currently used in the industrial flotation of copper sulphide ores (collectors: potassium dialkyl-dithiophosphate; mercaptan and xanthate, total dosage $32 \mathrm{~g} / \mathrm{t}$; frothers: DowFroth 250 and methyl isobutyl Carbinol, total dosage $27.5 \mathrm{~g} / \mathrm{t}$ ) was also conducted. When either biosolids or humic acids were used as both collector and frother a dosage of $10 \%(\mathrm{w} / \mathrm{w}$, dry basis) or $1.5 \%(\mathrm{w} / \mathrm{w}$, dry basis) were added, respectively. These dosages are equivalent when they are expressed in grams of humic substances per tonne of ore. For these tests, no additional commercial frother was used. All tests were conducted in triplicate.

The procedure involved adding $1 \mathrm{~kg}$ of copper sulphide ore in the Denver cell containing $3 \mathrm{~L}$ of double-distilled water. A solid/ liquid ratio of $25 \%$ was maintained. The pulp was stirred at $1400 \mathrm{rpm}$ and the $\mathrm{pH}$ adjusted to 10.5 with $\mathrm{CaO}$ solutions. Then, commercial collectors and frothers, biosolids or humic acids were added, and the ore pulp was conditioned for $10 \mathrm{~min}$. At the end of the conditioning period, atmospheric air was introduced into the cell at a rate of $4.5 \mathrm{~L} / \mathrm{min}$. The total flotation time was $18 \mathrm{~min}$.

For evaluating the effect of complete or partial (50\%) replacement of the main collector (a xanthate type) used at a Chilean mining company flotation plant with humic acids, rougher flotation tests were conducted at the metallurgical laboratory of this plant in a Wemco Cell and using the copper sulphide ore from the centralsouthern region of Chile. Again, for comparison, froth flotation tests using the same dosages of commercial collectors and frothers used at a mining company operation were conducted. These dosages are: $38 \mathrm{~g} / \mathrm{t}$ of the main collector (xanthate type) and $12 \mathrm{~g} / \mathrm{t}$ frothers (Dow Froth plus MIBC).

Fig. 2 presents a schematic diagram of the experimental rougher froth flotation procedure followed at a mining company metallurgical laboratory. In the first stage, the copper sulphide ore was

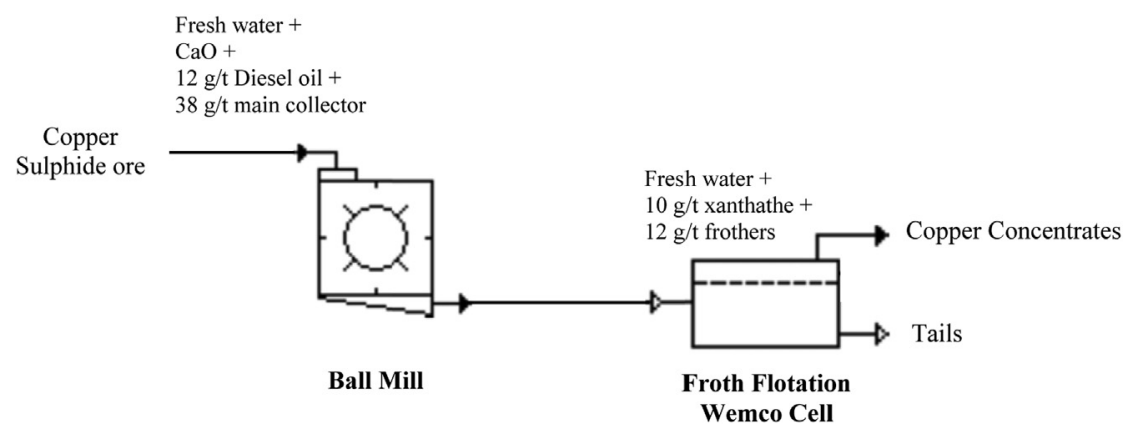

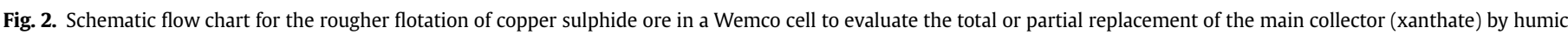
acids. 


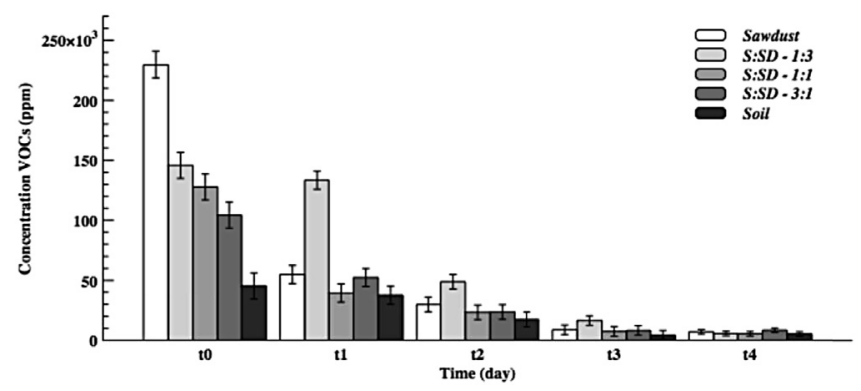

Fig. 3. Removal of VOCs from diesel and fuel oil-contaminated soil and sawdust after treatment in a vessel composting using different S:SD ratios: t0, initial conditions; $t 1$, 15 days; $\mathrm{t} 2,30$ days; $\mathrm{t} 3,45$ days; $\mathrm{t} 4,60$ days.

ground in a ball mill, mixing $1 \mathrm{~kg}$ of copper sulphide ore with $0.5 \mathrm{~L}$ of fresh water (drinking water). Next, CaO solution was added to set the $\mathrm{pH}$ at 10 , and $12 \mathrm{~g} / \mathrm{t}$ of diesel oil and $38 \mathrm{~g} / \mathrm{t}$ of the main collector were added. In the second stage, $1.83 \mathrm{~L}$ of fresh water, $10 \mathrm{~g} / \mathrm{t}$ of collector and $12 \mathrm{~g} / \mathrm{t}$ of frothers (DowFroth and methyl isobutyl Carbinol) were added into a Wemco cell. The pulp was conditioned for an additional $30 \mathrm{~s}$ and stirred at $1200 \mathrm{rpm}$. A solid/liquid ratio of $30 \%$ was maintained. Finally, atmospheric air at a rate of $4.5 \mathrm{~L} / \mathrm{min}$ was introduced into the cell. The total flotation time was $12 \mathrm{~min}$.

All rougher flotation tests were performed in triplicate. Solids recovered in the froth phase were separated from the liquid by filtration using Wathmann No. 42 filters. Then, the samples were dried at $80^{\circ} \mathrm{C}$ for $24 \mathrm{~h}$ and weighed. The total copper content of the concentrates and tailings was determined by atomic absorption spectrophotometry using a Perkin Elmer Analyst 300 apparatus.

\section{Results and discussion}

\subsection{Bioremediation of contaminated mining soil and sawdust}

Fig. 3 presents the results of aerobic remediation treatment of diesel and oil fuel-contaminated mining soil and sawdust. According to these results, with the exception of the $1: 3 \mathrm{~S}: \mathrm{SD}$ ratio, a significant removal of VOCs (over 60\%) was achieved after onemonth treatment. Abiotic controls did not show changes with time (data not shown). Therefore, the main removal of VOCs was due to biodegradation processes rather than physicochemical processes such as volatilization.

After one-month treatment, the removal of VOCs did not show statistically $\mathrm{t}$ differences to previous times at all $\mathrm{S}: \mathrm{SD}$ ratios according to a two-factor ANOVA test (factor 1, treatment (sawdust percentage); factor 2, time). Because our previous results indicate that both nutrient and VOC removal have a strong correlation (Godoy-Faúndez et al., 2008), the removal of VOCs in the present works is attributed to biodegradation processes. Microbial communities previously adapted to diesel and fuel oil pollutants may have conducted the biodegradation of these soil and sawdust contaminants. A biodegradation treatment such as composting promotes the removal of VOCs due to environmental conditions of mesophilic temperatures and humidity, thus increasing degradable metabolic activities.

This approach shows how sawdust can be used as a cheap adsorbent material for oil spills and its possible application for environmental remediation of diesel and fuel oil-contaminated soils from mining operations. Sawdust is a discarded material from forestry industries that can be used to produce energy by incineration or amended on ground. Energy production from sawdust is an economic process but it is not environment-friendly because of air emissions. Fig. 4 illustrates possible pathways for using sawdust for environmental benefits.

However, sawdust polluted with hydrocarbons needs to be contained and disposed of in hazardous waste landfills thereby increasing the environmental risks in mine closure. According to our results, polluted soil and sawdust mixed in different ratios can be treated by bioremediation in vessel composting decreasing the hazard of both wastes, which can be further applied to soil amendment in phytoremediation of heavy metals on tailings dams.

\subsection{Froth flotation tests}

Fig. 5 (left) shows the recoveries of copper and copper grade of the concentrates obtained by rougher flotation of a copper sulphide ore in a Denver cell using industrial collectors and frothers, and when either biosolids or humic acids are used to replace these flotation chemicals. Biosolids alone, at a dosage of $10 \%(\mathrm{w} / \mathrm{w}$, dry basis) recovered $26.0 \%$ of copper in the sulphide ore, with a grade of $0.8 \% \mathrm{Cu}$ in the concentrate. Humic acids alone, at a dosage of $1.5 \%$ (w/w, dry basis) recovered $29.7 \%$ of copper in the sulphide ore, and the grade of the concentrate was 3.5\% Cu. Using collectors and frothers currently used in the copper sulphide ore processing industry, the copper recovery was $65.6 \%$ and the grade of the concentrate $3.2 \% \mathrm{Cu}$. Therefore, these rougher flotation results indicate that humic acids have some potential to act as both collector and frother to concentrate copper sulphide ores by froth flotation.

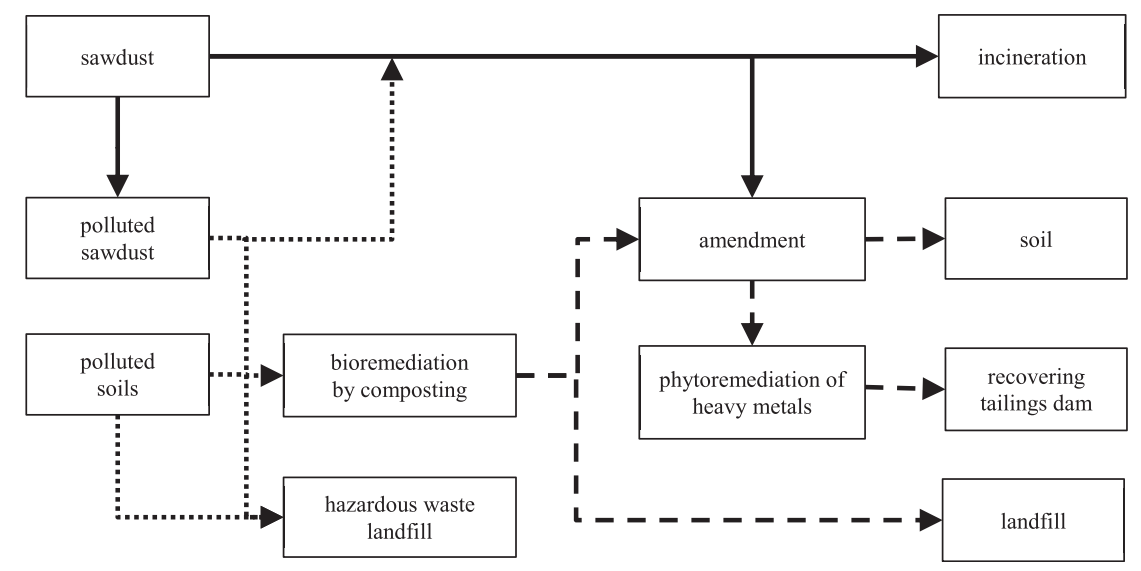

Fig. 4. Model of industrial ecology in bioremediation processing of polluted soils using sawdust as cheap adsorbent material. 

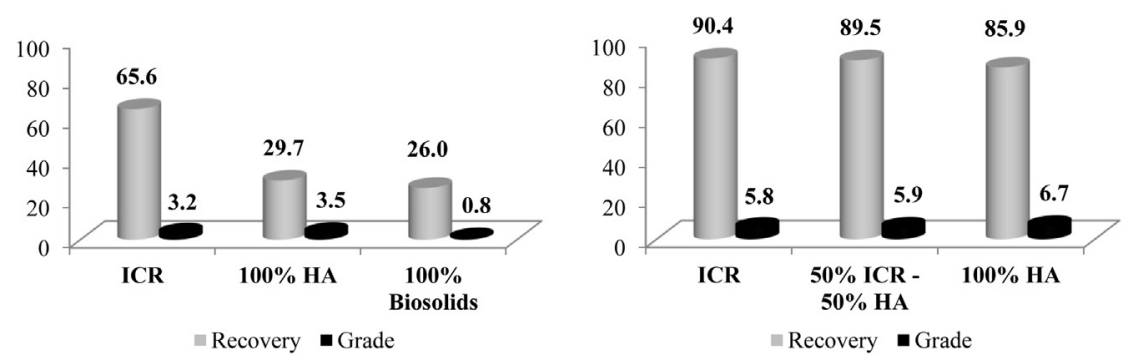

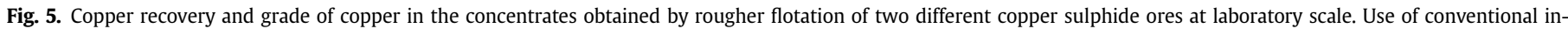

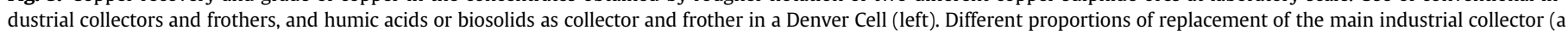

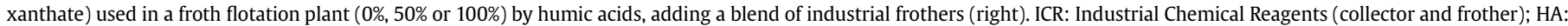
Humic Acids.

The possibility of complete or partial (50\%) replacement of the main collector, namely xanthate, used for the concentration of a copper sulphide ore at a Chilean mining company flotation plant with humic acids was then evaluated, and the obtained results are shown in Fig. 5 (right). These rougher flotation results, however, correspond to a different ore and were obtained using a Wemco cell because this equipment was available at the metallurgical laboratory of this plant. Following the protocol designed in this laboratory and adding a dosage of $38 \mathrm{~g} / \mathrm{t}$ of the main commercial collector and $12 \mathrm{~g} / \mathrm{t}$ of frothers, the copper recovery and concentrate grade obtained were $90.4 \%$ and $5.8 \% \mathrm{Cu}$, respectively. The total replacement of the main collector with the same dosage of humic acids $(38 \mathrm{~g} / \mathrm{t})$ shows that the copper recovery and concentrate grade obtained were $85.9 \%$ and $6.7 \% \mathrm{Cu}$, respectively. When humic acids replace $50 \%$ of the main collector, copper recovery is also a bit lower and the copper grade is a little higher.

The use of humic acids as main collector decreases the copper recovery $4.5 \%$ but increases the copper grade in the concentrate $0.9 \% \mathrm{Cu}$. This reduction in copper recovery with an increase in copper grade seems to indicate that humic acids are more selective to float copper sulphide minerals than the commercial collector used (i.e., a xanthate). A concentrate with a higher copper grade may make up the slight loss in recovery because unwanted material may pose some problems during treatment of this concentrate. Using a commercial xanthate as the main collector, copper recovery is higher and the copper grade is lower probably because more gangue minerals are also recovered in the concentrate. According to theoretical grade-recovery curves, it is not possible to have higher grade and higher recovery (Wills, 1992).

The results of rougher flotation tests for copper sulphide ores using a Denver cell or a Wemco cell cannot be compared because both the ore and the flotation conditions used are different for each case. Then, it is possible only compare the three results obtained for each cell but not for different cells. Nevertheless, rougher flotation results for the concentration of a copper sulphide ore at laboratory scale with humic acids as collector indicate that this reagent has potential for trying to substitute conventional collectors used in the current Chilean copper sulphide ore flotation processes with more environment-friendly chemicals.

The effect of biosolids addition on the hydrophobic properties of a copper sulphide ore has been evaluated by Reyes-Bozo et al. (2011a) in order to propose a new and novel alternative for the use of these solid waste materials in the froth flotation of these ores. Biosolids used in the present work are composed of organic matter ( $55 \% \mathrm{w} / \mathrm{w}$, dry basis), protein (20\%), aminoacids and sugars $(1 \%-3 \% \mathrm{w} / \mathrm{w})$. Additionally, biosolids also contain humic substances, mainly fulvic and humic substances (15\%-30\%) (Metcalf and Eddy, 2003; Reyes-Bozo et al., 2011b). Our previous results clearly indicate that biosolids and humic substances can change the hydrophobic properties of copper sulphide ores. Biosolids show greater affinity for pyrite while humic substances show similar behavior to industrial collectors. We have also reported the use of biosolids and humic substances as frother agents (Reyes-Bozo et al., 2011b), quantifying their ability to form and stabilize foams. Biosolids show a tensoactive effect similar to an industrial chemical frother, namely methyl isobutyl carbinol. Biosolids as well as humic acids are capable of changing the surface tension of a solution, thus creating and stabilizing froths.

Based on these results, it is possible to propose the integration of wastewater treatment plants with copper sulphide ore concentrators, as shown in Fig. 6, for aiding the greening of the overall copper mining process and its cleaner production from natural resources.

\subsection{Industrial ecology model for greening the Chilean copper sulphide mining processes}

The model proposed in this research may be applied in the central region of Chile where copper production and biosolids generation take place in close proximity. Geographic proximity is fundamental to minimize costs and impacts of biosolids

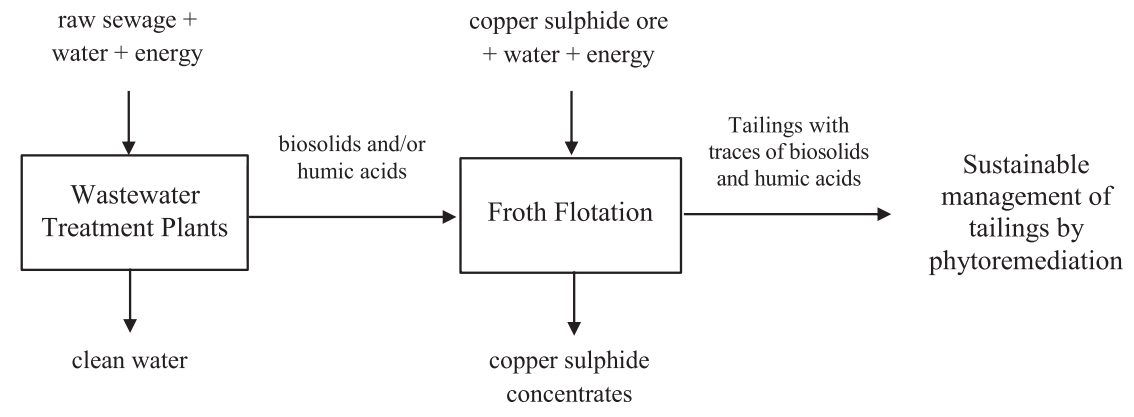

Fig. 6. Schematic representation of the proposed integration of biosolids generated in wastewater treatment plants with froth flotation of copper sulphide ores. 


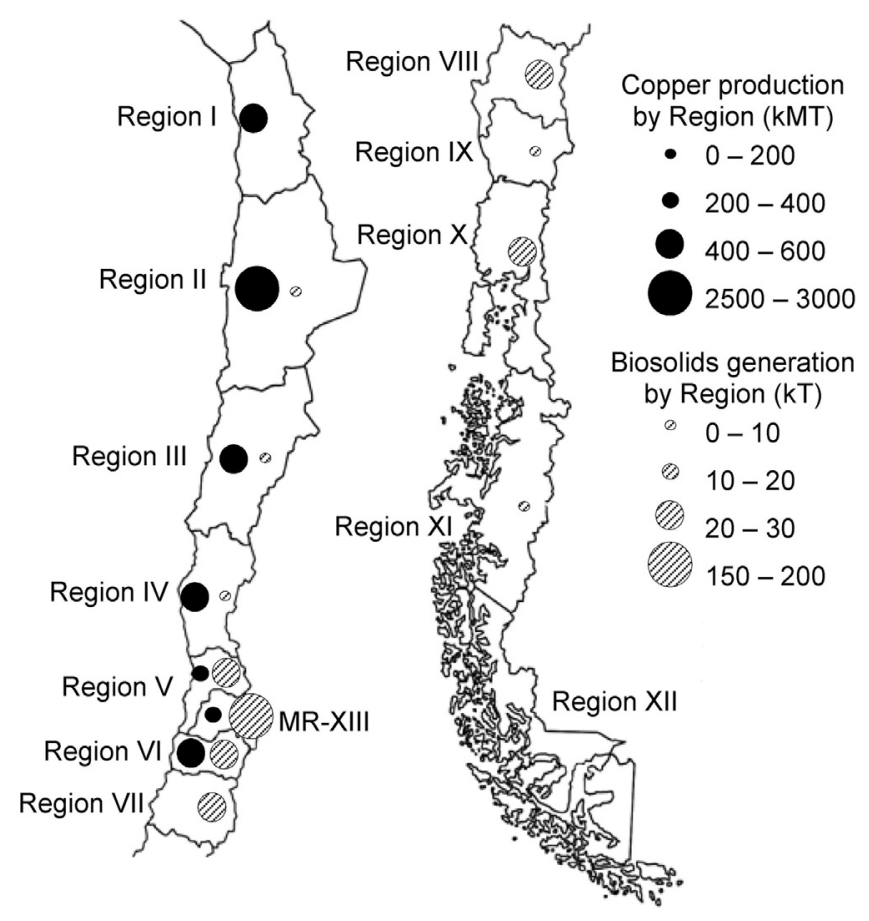

Fig. 7. Distribution of copper production and biosolids generation along Chile in 2011.

transportation as well as for facilitating material exchange between waste generators and copper producers (Fig. 7).

The use of wastes such as sawdust from forest industry sawmills (Godoy-Faúndez et al., 2008) as well as of biosolids from wastewater treatment plants (Reyes-Bozo et al., 2011a, 2011b, 2011c) may positively contribute to greening the copper mining industry of Chile. By combining Figs. 4 and 6, it is possible to propose an industrial ecology model that incorporates the use of wastes from the forestry industry and wastewater treatment plants into the froth flotation of copper sulphide ores. This model is schematically represented in Fig. 8.

\subsection{Economic, environmental and social aspects of copper sulphide ore flotation}

\subsubsection{Economic issues}

Different dosages of chemical reagents-mainly collectors, frothers and modifiers - are used in industrial froth flotation processes (Mpongo and Siame, 2006; Hadler et al., 2005; Sheridan et al., 2002), according to the physicochemical properties of ores being concentrated and the operating conditions. The reported dosages of froth flotation reagents imply that the cost associated with these reagents could be marginal in an industrial operation, but in the case of copper sulphide ores the increasing scale of ore extraction and processing due to decreasing average copper ore grade as well as complexity determines high requirements of these reagents, and consequently, high costs (e.g. if 80,000 tonnes/day milled ore are processed by froth flotation, the cost of chemical reagents per day is about USD12,000).

According to Cochilco's statistics (2013b), in the year 2011 Chile processed 527 million tonnes of copper sulphide ore by froth flotation. For the same year, the average copper grade was $0.94 \%$ and an average recovery of $87.8 \%$ copper was estimated. In froth flotation reagents, USD 147 million were spent annually: USD 29 million for frothers, USD 31 million for collectors, USD 22 million for flocculants and USD 65 million for modifiers ( $\mathrm{pH}$ control).

Based on the results described for copper sulphide ore from the central-southern region of Chile, the main collector of this mining operation has a market cost of $3 \mathrm{USD} / \mathrm{kg}$ (plant price). The use of humic acids as useful collector for copper concentration will have an estimated final cost of about 2.1 USD/kg (Achurra Cofré, 2013). This price is the most competitive obtained from a sensitivity analysis in which the initial selling price was varied as well as the sale price, initial sales volume, sales growth, license fee and the cost structure of a company to transfer technology to the mining industry.

Therefore, the use of biosolids and/or humic acids as frother and collector agents would be cheaper and would lower costs associated with the concentration step. Additionally, the use of biosolids may keep operational costs to a minimum while maximising revenue. Moreover, biosolids may improve economic performance of mining processes by lowering health costs, production costs (i.e.,

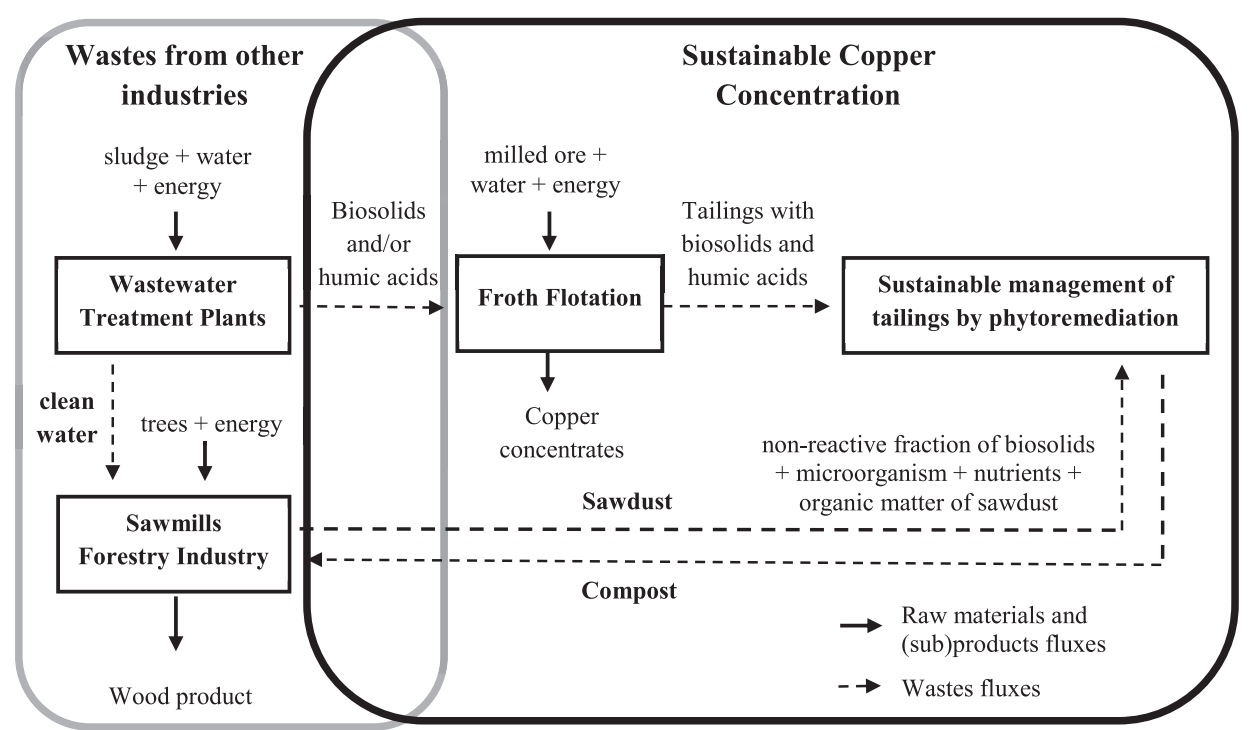

Fig. 8. Schematic representation of the proposed industrial ecology model for greening Chilean copper sulphide ore flotation plants. 
humic substances have a similar kinetics of recovery as chemical reagents) (Reyes-Bozo et al., 2011c), and closure costs, since biosolids could also be used for sustainable management of tailings via biological treatment.

Current Chilean regulation (Minsegpres, 2009) allows the final disposal of biosolids in mining areas. Therefore, the use of biosolids as collector and frother allows an adequate final disposal and lower cost associated with disposal of biosolids in monofills or codisposal in landfills, because it is estimated that the cost of transportation and final disposition of biosolids from a wastewater treatment plant from the central-southern region of Chile is about $0.05 \mathrm{USD} / \mathrm{kg}$. Therefore, considering an annual output of 160,000 tonnes of biosolids approximately USD 8 million per year may be saved in disposal costs.

\subsubsection{Environmental issues}

Chemical reagents used in froth flotation are expensive and pose environmental risks as hazardous materials because of their potential health effects. Many of these chemical reagents, besides being toxic, flammable and irritant to eyes and respiratory system, are persistent compounds which are partially disposed of in tailings due to excessive dosages. Thus, manipulation in the operational stage should be carefully managed owing to their toxicity. At the same time, some chemical reagents produce high environmental stress for operational staff due to generated odors. Therefore, biosolids can be used as new environment-friendly froth flotation reagents since these substances, as biodegradable material, are innocuous for both mining processes and human health. In addition, sawdust (a solid waste from the forestry industry) could be used as cheap adsorbent of diesel and fuel oil-contaminated mining soils and to support biological strategies such as phytoremediation for safe management of tailings.

\subsubsection{Community and social issues}

Chile, in spite of having a strongly growing economy, with prospects for achieving improved development soon, faces a big challenge: how to manage growing inequality. Because the Chilean economy is based on natural resources exploitation, overall impacts due to industrial activities are not included in national accounts; therefore, the environmental costs of development remain unknown. A challenge of Chile's mining industry is how to prevent environmental injustices. This injustice is due to high environmental inequalities between the population living near and far from mining sites. These impacts need to be deducted from economic benefits by income per household since they produce detrimental outcomes in both human and ecosystem health.

A model of industrial ecology allows lower socio-economic risks. Bioremediation process converts hazardous, contaminated soil and sawdust wastes into innocuous materials such as amended soils. This remediated waste can then be used for reforestation and phytoremediation of heavy metals on tailings dams. Processing of these polluted materials decreases the environmental risks of population exposure to hazardous materials. Lower environmental risks reduce economic impacts affecting the mining industry due to reduction of costs into planning of hazardous landfills in mine closure operations. Finally, an industrial ecology model could help to improve population quality of life by minimizing the environmental impacts through lower chemical reagent consumption, reducing hazardous waste generation and converting wastes into less dangerous materials. This model may also reduce environmental and social conflicts thus improving people's perception of mining industry performance, and building trust and confidence among stakeholders.

\section{Conclusions}

Sawdust - a solid waste generated by the forestry industries was used as a cheap adsorbent for the bioremediation of a diesel and fuel oil-contaminated mining soil. The amount of VOCs present in this soil was significantly reduced after one-month treatment in aerobic reactors. Another solid waste, namely biosolids - generated at municipal wastewater treatment plants - was used as collector and frother for the flotation of a copper sulphide ore. These biosolids have shown to have good frothing characteristics and also to act as collector of copper sulphide minerals. Because biosolids contain humic acids, these organic acids were also tested as main collector for the flotation of a copper sulphide ore. In the case of humic acids flotation of a copper sulphide ore, a reduction in recovery with an increase in grade seems to indicate that humic acids are more selective to float copper sulphide minerals than the commercial collector used. Based on these results, an ecology model that incorporates the use of environment-friendly solid wastes is proposed for greening the Chilean copper sulphide mineral industry and to aid in the cleaner production of copper. This model may contribute to improve the overall environmental sustainability of copper sulphide ores flotation by complete or partial replacement of traditional collectors and frothers for less hazardous materials and chemical reagents. Nevertheless, further research is needed to scale-up current laboratory results to industrial mineral processing operations and more research is needed to refine the use of humic acid as main collector for copper sulphide ore to ensure there is no loss of recovery.

\section{Acknowledgments}

This research was partially funded by Chile's Conicyt program through the National Fund for Scientific and Technological Research (Fondecyt) via No. 11121159 Project. Additional support came from a research grant from Universidad Andres Bello, Project DI-20-12/R (L. Reyes-Bozo).

\section{References}

Achurra Cofré, G., 2013. Creación de una empresa de Base Tecnológica. Bioflotación: Un Spin-off desde la Universidad Católica de Chile hacia la Industria Minera Chilena. Tesis de Magíster. Pontificia Universidad Católica de Chile, Santiago, Chile.

Al-Awadhi, N., Al-Daher, R., EINawawy, A., Salba, M.T., 1996. Bioremediation of oilcontaminated soil in Kuwait. I. Landfarming to remediate oil-contaminated soil. J. Soil. Contam. 5, 243-260.

Antizar-Ladislao, B., Lopez-Real, J.M., Beck, A.J., 2004. Bioremediation of polycyclic aromatic hydrocarbon (PAH)-contaminated waste using composting approaches. Crit. Rev. Env. Sci. Tecnol. 34, 249-328.

Antizar-Ladislao, B., Lopez-Real, J., Beck, A.J., 2006. Degradation of polycyclic aromatic hydrocarbons (PAHs) in an aged coal-tar contaminated soil under invessel composting conditions. Environ. Pollut. 141, 459-468.

Basu, A.J., van Zyl, D.J.A., 2006. Industrial ecology framework for achieving cleaner production in the mining and minerals industry. J. Clean. Prod. 14, 299-304.

Biswas, A.K., Davenport, W.G., 2002. Extractive Metallurgy of Copper, fourth ed. Pergamon Press, Oxford.

Bulatovic, M., 2007. Handbook of Flotation Reagents: Chemistry, Theory and Practice. In: Flotation of Sulfide Ores, first ed, vol. 1. Elsevier Science, The Netherlands. 446 p.

Campbell, H.W., 2000. Sludge management-futures issues and trends. Water Sci. Technol. 41 (8), 1-8.

Chockalingam, E., Subramanian, S., Natarajan, K.A., 2003. Studies on biodegradation of organic flotation collectors using Bacillus polymyxa. Hydrometallurgy 71 249-256.

Cochilco, Chilean Copper Commission, 2012. Yearbook: Copper and other mineral statistics 1993-2012. Santiago, 172 p.

Cochilco, Chilean Copper Commission, 2013a. Inversión en la minería Chilena: Cartera de Proyectos 2013-2021.

Cochilco, Chilean Copper Commission, 2013b. Oportunidades de negocios para proveedores de bienes, insumos y servicios mineros en Chile. Santiago, 49 p.

Cochilco, Chilean Copper Commission, 2013c. Inversión, exploración e insumos estratégicos para la minería. Santiago, 322 p. 
ECLAC, 2010. . Economics of Climate Change in Latin America and the Caribbean, Summary 2010. UN ECLAC, 107 pp.

Gaines, V.R., Skinner, W.C., Foord, E.E., Mason, B., Rosenzweig, A., 1997. Dana's New Mineralogy, eighth ed. John Wiley \& Sons, Inc.

Guellil, A., Boualam, M., Quiquampoix, H., Ginestet, P., Audio, J.M., Block, J.C., 2001. Hydrolysis of wastewater colloidal organic matter by extra-cellular enzymes extracted from activated sludge flocs. Water Sci. Technol. 43 (6), 33-40.

Godoy-Faúndez, A., Antizar-Ladislao, B., Reyes-Bozo, L., Camaño, A., SáezNavarrete, C., 2008. Bioremediation of contaminated mixtures of desert mining soil and sawdust with fuel oils by aerated in-vessel composting in the Atacama Region (Chile). J. Hazard. Mater. 151 (2-3), 649-657.

Gunson, A.J., Klein, B., Veiga, M., Dunbar, S., 2012. Reducing mine water requirements. J. Clean. Prod. 21 (1), 71-82.

Hadler, K., Aktas, Z., Cilliers, J.J., 2005. The effects of frother and collector distribution on flotation performance. Min. Eng. 18, 171-177.

Herrera-Urbina, R., 2003. Recent developments and advances in formulations and applications of chemical reagents used in froth flotation. Min. Process. Extr. M. 24, 139-182.

Langer, M., 1998. Geoenvironmental aspects of waste disposal. Environ. Geol. 35, 1-2.

Laurence, D., 2011. Establishing a sustainable mining operation: an overview J. Clean. Prod. 19, 278-284.

LeBlanc, R.J., Matthews, P., Richard, R.P., 2008. Global Atlas of Excreta, Wastewater Sludge, and Biosolids Management: Moving Forward the Sustainable and Welcome Uses of a Global Resource. United Nations, Kenya.

McFarland, M., 2000. Biosolids Engineering. McGraw-Hill Professional, 800 p.

McLellan, B.C., Corder, G.D., Giurco, D., Green, S., 2009. Incorporating sustainable development in the design of mineral processing operations - review and analysis of current approaches. J. Clean. Prod. 17, 1414-1425.

McLellan, B.C., Corder, G.D., 2012. Risk reduction through early assessment and integration of sustainability in design in the minerals industry. J. Clean. Prod. 53, 37-46.

Memary, R., Giurco, D., Mudd, G., Mason, L., 2012. Life cycle assessment: a timeseries analysis of copper. J. Clean. Prod. 33, 97-108.

Metcalf, L., Eddy, H., 2003. Wastewater Engineering. Treatment and reuse, fourth ed. MacGraw-Hill.

Minsal, Ministerio de Salud, 2004. Decreto Supremo No. 148: Reglamento Sanitario Sobre Manejo de Residuos Peligrosos (Sanitary normative on handling hazardous wastes). Santiago, República de Chile.

Minsegpres, Ministerio, 2009. Secretaría General de la Presidencia. Decreto Supremo No. 4: Reglamento para el manejo de lodos generados en Plantas de Tratamiento de aguas servidas. Santiago, República de Chile.

Mpongo, M.K., Siame, E., 2006. Effect of collector, frother and depressant addition on the copper recovery and concentrate grade of the nchanga underground scavenger circuit of Konkola copper mine - Zambia. Afr. J. Sci. Technol. 7, 8-11.

Moors, E.H.M., Mulder, K.F., Vergragt, P.J., 2005. Towards cleaner production: barriers and strategies in the base metals producing industry. J. Clean. Prod. 13, $657-668$.

Murray, A., Horvath, A., Nelson, K.L., 2008. Hybrid life-cycle environmental and cost inventory of sewage sludge treatment and end-use scenarios: a case study from China. Environ. Sci. Technol. 42, 3163-3169.

Northey, S., Haque, N., Mudd, G., 2013. Using sustainability reporting to assess the environmental footprint of copper mining. J. Clean. Prod. 40, 118-128.

Oyarzún, J., Oyarzún, R., 2011. Sustainable development threats, inter-sector conflicts and environmental policy requirements in the arid, mining rich, northern Chile territory. Sustain. Dev. 19 (4), 263-274.
Pandey, A.K., Pandey, S.D., Misra, V., Viswanathan, P.N., 1999. Formation of soluble complexes of metals with humic acid and its environmental significance. Chem. Ecol. 16 (4), 269-282.

Park, C., Novak, J.T., Helm, R.F., Ahn, Y., Esen, A., 2008. Evaluation of the extracellular proteins in full-scale activated sludges. Water Res. 42, 3879-3889.

Ralston, I.D., 2002. The Process, Health, Safety and Engineering Issues Related to the Storage and Use of Xanthates. ATD Report No. PRE-2002-003, Mayo de 2002, Anglo American.

Reyes-Bozo, L., Herrera-Urbina, R., Escudey, M., Godoy-Faúndez, A., SáezNavarrete, C., Herrera, M., Ginocchio, R., 2011a. Role of biosolids on hydrophobic properties of sulfide ores. Int. J. Min. Process 100, 124-129.

Reyes-Bozo, L., Herrera-Urbina, R., Godoy-Faúndez, A., Sáez-Navarrete, C., Herrera, M., Ginocchio, R., 2011b. Uso de biosólidos como reactivo espumante en procesos de flotación: caracterización física y química. Dyna Rev. Fac. Nac. Minas 78 (167), 66-73.

Reyes-Bozo, L., Herrera-Urbina, R., Sáez-Navarrete, C., Otero, A.F., GodoyFaúndez, A., Ginocchio, R., 2011c. Rougher flotation of copper sulphide ore using biosolids and humic acids. Min. Eng. 24, 1603-1608.

Sadzawka, A., Carrasco, M.A., Grez, R., Mora, M.L., Flores, H., Neaman, A., 2006. Métodos de análisis recomendados para los suelos de Chile. Instituto de Investigaciones Agropecuarias (INIA), Santiago, Chile.

Schmidt-Hebbel, K., 2012. Fiscal policy for commodity exporting countries: Chile's experience. Documento de Trabajo 415. Instituto de Economía. Pontificia Universidad Católica de Chile.

Sheridan, M.S., Nagaraj, D.R., Fornasiero, D., Ralston, J., 2002. The use of a factorial experimental design to study collector properties of N-allyl-O-alkyl thionocarbamate collector in the flotation of a copper ore. Min. Eng. 15, 333340 .

Singh, R.P., Agrawal, M., 2008. Potential benefits and risks of land application of sewage sludge. Waste Manag. 28, 347-358.

SISS, Superintendencia de Servicios Sanitarios, 2010. Informe de gestión del sector sanitario 2010. SISS, Santiago, 164 pp.

Sommers, L.E., 1977. Chemical composition of sewage sludges and analysis of their potential use as fertilizers. J. Environ. Qual. 6, 225-232.

Subramanian, S.V., Kawachi, I., 2004. Income inequality and Health: what have we learned so far? Epidemiol. Rev. 26 (1), 78-91.

Tan, S.N., Pugh, R.J., Fornasiero, D., Sedev, R., Ralston, J., 2005. Foaming of polypropylene glycols and glycol/MIBC mixtures. Min. Eng. 18, 179-188.

US EPA, 1995. Sewage Sludge Incineration AP-42.

US EPA, 2005. USEPA SW846. Methods for Evaluating Solid Wastes Physical/ Chemical Methods, 8000 Series: Method 8260B-Method 8270, available in: http://www.epa.gov/epaoswer/hazwaste/test/8_series.htm.

USDoA, US Department of Agriculture, 1999. Soil Taxonomy, a Basic System of Soil Classification for Making and Interpreting soil surveys. U.S. Government Printing Office.

Verdugo, C., Sánchez, P., Santibáñez, C., Urrestarazu, P., Bustamante, E., Silva, Y., Gourdon, D., Ginocchio, R., 2010. Efficacy of lime, biosolids, and mycorrhiza for the phytostabilization of sulfidic copper tailings in Chile: a greenhouse experiment. Int. J. Phytoremediat. 13, 107-125.

Wei, Q.F., Lowery, B., Peterson, A.E., 1985. Effect of sludge application on physical properties of a silty clay loam soil. J. Environ. Qual. 14, 178-180.

Wills, B.A., 1992. Mineral processing Technology: an Introduction to the Practical Aspects of Ore Treatment and Mineral Recovery, fifth ed. Pergamon Press, Oxford. 